\title{
JENIS KELAMIN HIU TUPAI (Chiloscyllium hasselti) BERDASARKAN KARAKTER MORFOLOGI DAN MORFOMETRI
}

\author{
Nurlaini Laili, Mufti Sudibyo \\ Program Studi Biologi, Universitas Negeri Medan Jl. William Iskandar Psr V Medan Estate \\ lainilaili@gmail.com
}

\begin{abstract}
ABSTRAK
Tujuan penelitian ini adalah mengetahui perbedaan morfologi dan morfometri Hiu Tupai (Chiloscyllium hasselti) jantan dan betina serta mengetahui faktor yang berkontribusi terhadap panjang total tubuh Hiu Tupai Jantan dan Betina. Sampel penelitian di ambil dari Pusat Pasar Ikan di Jl. Cemara Sampali Medan. Sampel Hiu Tupai (Chiloscyllium hasselti) yang diamati diambil sebanyak 35 jantan dan 35 betina. Karakter morfologi diperoleh dengan cara mengamati seluruh bagian tubuh antara jantan dan betina. Analisis statistik untuk membedakan antara jantan dengan betina menggunakan uji $t$, sedangkan untuk mengetahui faktor yang berkontribusi terhadap panjang total menggunakan analisis regresi berganda metode stepwise. Hasil penelitian menunjukkan bahwa secara morfologi Hiu Tupai (Chiloscyllium hasselti) jantan dan betina berbeda pada bagian kepala (betina memiliki bentuk kepala dengan ujung membulat sedangkan jantan meruncing) dan organ reproduksi (jantan memiliki klasper sedangkan betina memiliki kloaka). Berdasarkan hasil uji t diketahui terdapat 12 perbedaan karakter morfometri Hiu Tupai (Chiloscyllium hasselti) jantan dan betina. Secara morfometri karakter yang paling tinggi kontribusinya terhadap panjang total tubuh jantan yaitu panjang moncong hingga sebelum sirip dorsal pertama $\left(X_{2}\right) 97,3 \%$, panjang standard $\left(X_{1}\right) 98,3 \%$, panjang klasper $\left(X_{20}\right) 99,1 \%$, jarak antara sirip dorsal pertama dan kedua $\left(X_{8}\right) 99,3 \%$, dan panjang ekor $\left(X_{18}\right)$ 99,5\% dan panjang moncong hingga sebelum kepala $\left(X_{5}\right)$ 99,6\%. Sedangkan pada Hiu betina karakter morfometri yang paling tinggi kontribusinya yaitu panjang standard $\left(X_{1}\right) 95,7 \%$, panjang mulut $\left(X_{14}\right) 97,7 \%$, panjang ekor $98,6 \%$, jarak antara sirip dorsal pertama dan kedua $\left(X_{8}\right) 98,9 \%$, panjang sirip anal $\left(X_{19}\right) 99,1 \%$ serta panjang sirip perut $\left(\mathrm{X}_{11}\right)$ 99,6\%.
\end{abstract}

Kata kunci : Morfologi, Morfometri, Chiloscyllium hasselti, Jenis Kelamin.

\section{THE SEXES OF TUPAI SHARK (Chiloscyllium hasselti) BASED ON CHARACTERISTIC OF MORPHOLOGY AND MORPHOMETRY}

\begin{abstract}
The aims of this research are to know the differences of morphology and morphometry of male and female Tupai Shark (Chiloscyllium hasselti) as well as to know the factors which contiributes to the total length of body of Male and Female Tupai Shark.The sample was taken from the Pusat Pasar Ikan located on Jln. Cemara Sampali Medan. The Samples of Tupai Shark (Chiloscyllium hasselti) which observed were taken as many as 35 males and 35 females. The morphology characters were obtained by observing all parts of the body between males and females. Statistical analysis has done to distinguish between males and females using $t$ test while the contributing factors for total length analyzed using multiple regression by stepwise methods. The results showed that morphology between males and females Tupai Shark (Chiloscyllium hasselti) were different from head (The female has rounded head, while male pointed head) to organ of reproduction (the clasper in male while the cloaca in females). Based on the result of $t$ test showed there were 12 differences between male and female Tupai shark (Chiloscyllium hasselti). The morphometry characters with the highest contribution to the total length of the body males is pre second dorsal length $\left(X_{2}\right) 97,3 \%$, standard length $\left(X_{1}\right)$ 98,3\%, clasper length $\left(X_{20}\right)$ 99,1\%, inter dorsal length $\left(X_{8}\right)$ 99,3\%,caudal length $\left(X_{18}\right)$ $99,5 \%$, prebranchial length $\left(X_{5}\right) 99,6 \%$. While of the Female characters with the highest contribution to the total length of the body is standard length $\left(X_{1}\right) 95,7 \%$, mouth length $\left(X_{14}\right) 97,7 \%$, caudal length $\left(X_{18}\right) 98,6 \%$, inter dorsal length $\left(X_{8}\right) 98,9 \%$, anal fins length $\left(X_{19}\right) 99,1 \%$ and pelvic length $\left(X_{11}\right) 99,6 \%$.
\end{abstract}

Keyword: Morphology, Morphometry, Chiloscyllium hasselti, Sexes 


\section{Pendahuluan}

Indonesia memiliki keragaman jenis Hiu yang cukup tinggi, setidaknya 116 jenis ikan Hiu yang termasuk ke dalam 25 suku di temukan di wilayah perairan Indonesia. Namun kondisi saat ini menunjukkan bahwa hampir seluruh jenis ikan Hiu yang bernilai ekonomis telah dihadapkan kepada ancaman kelangkaan.Tercatat satu jenis Hiu di Indonesia telah dikategorikan sebagai sangat terancam (critically endangered), 5 jenis yang termasuk terancam (endangered), 23 jenis yang termasuk kategori rawan punah (vulnerable), serta 35 jenis hiu yang termasuk dalam kategori hampir terancam (near threatened) (Dharmadi dan Fahmi, 2013).

Salah satu jenis Hiu yang hampir terancam punah adalah Chiloscyllium hasselti (IUCN, 2016). Chiloscyllium hasselti atau Indonesian bamboo shark termasuk dalam ordo Orectolobiformes dengan famili Hemiscylliidae yang memiliki ciri moncong bulat dan tumpul, memiliki spirakel yang besar dan bereproduksi dengan cara bertelur (ovipar). Hiu ini banyak ditemukan di perairan Indonesia khususnya perairan Sumatera dan Jawa (Compagno, 2001).

Bedasarkan sifat biologinya Hiu memiliki pertumbuhan yang lambat, berumur panjang, lambat dalam mencapai matang secara seksual dan memiliki jumlah anakan yang sedikit (Camhi et al., 1998). Dengan demikian Hiu menjadi sangat rentan terhadap laju kematian akibat penangkapan. Apabila sudah tereksploitasi secara berlebihan akan mengakibatkan ikan Hiu menjadi sangat mudah terancam punah jika dibandingkan dengan kelompok ikan jenis lain (Bangun, 2014).

Chiloscylium hasselti banyak ditemukan di perairan dekat pantai dan terumbu karang (Compagno, 2001). Keberadaan Hiu Chiloscyllium hasselti sangat penting dalam menjaga ekosistem laut dan terumbu karang karena sifat Hiu sebagai predator utama. Camhi et al., (1998) menambahkan Hiu memegang peranan penting dalam sistem ekologi sebagai predator puncak (apex predator). Sebagai predator puncak, Hiu memangsa hewanhewan yang berada pada tingkat tropik di bawahnya sehingga secara tidak langsung hiu ikut menjaga dan mengatur keseimbangan ekosistem laut dengan melakukan seleksi dalam ekosistem dan mengatur jumlah populasi hewan-hewan di dalam tingkat tropik yang lebih rendah (WWF, 2015).

Para pedagang ikan di Pasar ikan Cemara Sampali menyebut Chiloscyllium hasselti sebagai Hiu Tupai. Hiu ini banyak diperjual belikan di Pusat pasar ikan Cemara Sampali. Chiloscyllium hasselti yang ditemukan di Pasar ikan Cemara Sampali memiliki ciri morfologi yaitu memiliki sisi sirip dorsal bagian belakang yang berbentuk cembung, permulaan sirip pektoral terletak pada insang kedua atau ketiga, tidak ada pola warna pada dewasa tidak jauh berbeda dengan yang ciri yang dikemukakan oleh (Ali et al., 2013).

Informasi saat ini menunjukkan bahwa Chiloscyllium hasselti belum banyak diteliti. Menurut Faizah dan Umi, (2015) ketersediaan data biologi hiu dan kelompok ikan bertulang rawan pada umumnya masih kurang memadai bila dibanding dengan data biologi dari jenis ikan bertulang keras (teleostei). Informasi data biologis Hiu sangat penting bagi pengelolaan perikanan dan sangat dibutuhkan untuk memperoleh data yang akurat dalam penentuan kebijakan (White et al., 2006). Penetuan kebijakan tersebut dapat dilakukan dengan cara implementasi aturan CITES di Indonesia dengan cara menerapkan regulasi terkait penetapan status perlindungan Hiu, kuota tangkap, data ilmiah mengenai Hiu (Bangun, 2014).

Pengamatan secara morfologi dapat membedakan antara individu jantan dan betina. Mereka dapat dibedakan dari ukuran panjangnya, bentuk dan tekstur sirip, warna, organ reproduksi, bentuk kepala (Idris et al., 2012). Perbedaan morfologi dapat berdampak pada aspek biologi seperti cara mendapatkan makanan, kompetisi, habitat yang digunakan (Piorski dan Nunes, 2001) dan umur serta pertumbuhannya (Chen et al., 2007).

Pengenalan Hiu selama ini bagi masyarakat maupun mahasiswa hanya terbatas pada karakter morfologi sedangkan karakter morfometri pada spesies Hiu masih sangat jarang di teliti untuk itu penelitian diarahkan ke morfometri untuk mengetahui faktor apa yang paling menetukan terhadap karakter jenis berdasarkan kontribusi terhadap panjang total tubuh.

\section{Bahan dan Metode}

Penelitian dilakukan ini pada bulan Maret Mei 2017. Pengambilan sampel dilakukan di Pasar Ikan Cemara Sampali Medan. Pengambilan Sampel sebanyak 70 ekor yang terdiri dari 35 Hiu jantan dan 35 Hiu betina. Alat dan bahan yang digunakan adalah Kamera 16,2 mega pixel, Memory card, Pita meter, Buku catatan.

Pengambilan sampel Hiu Chiloscyllium hasselti di Pusat pasar Ikan Cemara Sampali Medan. Sampel Hiu Chiloscyllium hasselti kemudian diamati karakter morfologi.. Karakter- karakter morfologi yang diamati bentuk kepala, bentuk moncong, bentuk sirip punggung, adanya sirip anal, letak celah insang dan jenis kelamin. Hasil perbedaan antara 
karakter morfologi antara Hiu Tupai jantan dan betina tersebut dicatat dan di dokumentasikan. Setelah itu dilakukan pengukuran terhadap tiap-tiap karakter morfometri Hiu Tupai jantan dan betina. Selanjutnya hasil pengukuran tiap karakter morfometri tersebut dicatat dan di dokumentasikan.

Data pengukuran selanjutnya diolah dengan uji t (untuk perbedaan karakter morfometri jantan dan betina) dan regresi linear berganda dengan metode Stepwise (karakter morfometri yang berkontribusi terhadap panjang total tubuh jantan dan betina) diolah dengan bantuan software IBM SPSS Statistics 20 mengikuti formulasi:

$Y 1=b_{0}+b_{1} X_{1}+b_{2} X_{2}+b_{3} X_{3}+b_{4} X_{4}+\ldots .+b_{n} X_{n}$

$Y 2=b_{0}+b_{1} X_{1}+b_{2} X_{2}+b_{3} X_{3}+b_{4} X_{4}+\ldots .+b_{n} X_{n}$

Keterangan :

Y1 : Panjang total Chiloscyllium hasselti jantan (cm)

Y2 : Panjang total Chiloscyllium hasselti betina (cm)

$\mathrm{b}_{0}$ : Nilai intersep

$\mathrm{b}_{1}$ : Nilai koefisien regresi ke - $\mathrm{i}$

$\mathrm{X}_{1}=$ Panjang standart $/ \mathrm{PCL}(\mathrm{cm})$

$\mathrm{X}_{2}=$ Panjang moncong hingga sebelum sirip punggung pertama/ PD1 $(\mathrm{cm})$

$\mathrm{X}_{3}=$ Panjang moncong hingga sebelum sirip punggung kedua/ PD2 (cm)

$\mathrm{X}_{4}=$ Panjang kepala $/ \mathrm{HL}(\mathrm{cm})$

$\mathrm{X}_{5}=$ Panjang moncong hingga celah insang pertama /PGI (cm)

$\mathrm{X}_{6}=$ Panjang moncong hingga sebelum spirakel/PSP (cm)

$\mathrm{X}_{7}=$ Panjang moncong hingga sebelum orbital mata/ POB $(\mathrm{cm})$

$\mathrm{X}_{8}=$ Jarak antara sirip punggung pertama dan kedua/ IDL(cm)

$\mathrm{X}_{9}=$ Jarak antara sirip dada dan sirip perut/PPS (cm)

$\mathrm{X}_{10}=$ Panjang moncong hingga sebelum sirip perut /PPL(cm)

$\mathrm{X}_{11}=$ Panjang sirip perut/PSPE $(\mathrm{cm})$

$\mathrm{X}_{12}=$ Jarak antara moncong dengan mulut/PP $(\mathrm{cm})$

$\mathrm{X}_{13}=$ Lebar mulut $/ \mathrm{LM}(\mathrm{cm})$

$\mathrm{X}_{14}=$ Panjang mulut $/ \mathrm{PM}(\mathrm{cm})$

$\mathrm{X}_{15}=$ Panjang sirip punggung pertama/D1A $(\mathrm{cm})$

$\mathrm{X}_{16}=$ Panjang Sirip punggung kedua /D2A (cm)

$\mathrm{X}_{17}=$ panjang sirip dada $/ \mathrm{PSDA}(\mathrm{cm})$

$\mathrm{X}_{18}=$ Panjang Sirip Ekor $/ \mathrm{PE}(\mathrm{cm})$

$\mathrm{X}_{19}=$ Panjang Sirip Anal

$\mathrm{X}_{20}=$ Panjang Klasper / CLO (cm)

Hasil Dan Pembahasan

\section{Hasil}

Secara morfologi perbedaan antara Jantan dan Betina Hiu Tupai yaitu :

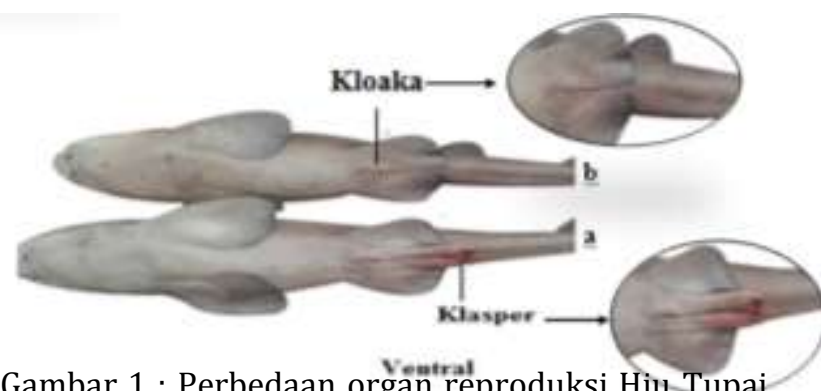

Gambar 1 : Perbedaan orgañ reproduksi Hiu Tupai (Chiloscyllium hasselti) jantan (a) dan betina (b)

Dari Gambar 1 diketahui bahwa Perbedaan morfologi Hiu Tupai (Chiloscyllium hasselti) jantan dan betina dapat dibedakan melalui organ reproduksinya. Hiu Tupai jantan memiliki klasper sedangkan pada Hiu Tupai betina memiliki kloaka. Klasper pada Hiu Jantan berfungsi sebagai alat kelamin jantan atau modifikasi sirip perut yang membentuk saluran sperma yang berfungsi menyalurkan sperma ke kloaka (organ reproduksi) pada betina.

Perbedaan morfologi selanjutnya Hiu Tupai Chiloscyllium hasselti jantan dan betina. terdapat pada bentuk kepala.

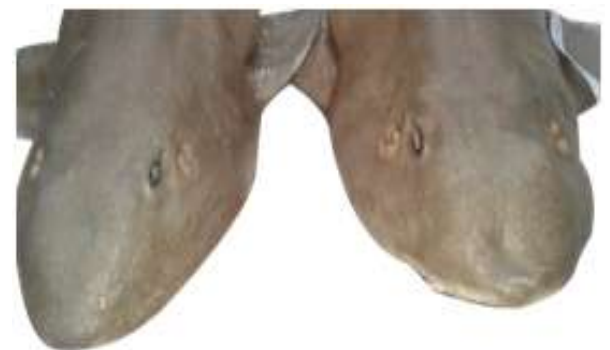

Jantan

Betina

\section{Morfometri Hiu Tupai (Chiloscyllium hasselti) Jantan dan Betina}


Tabel1. Karakter morfometri yang memberikan kontribusi terhadap panjang total pada Hiu Tupai (Chiloscyllium hasselti)Jantan.

No.

Morfometri

\section{Jantan (\%)}
$97,3 \%$
$98,3 \%$
$99,1 \%$
$99,3 \%$
$99,5 \%$
$99,6 \%$

Jarak antara sirip
Panjang ekor $\left(\mathrm{X}_{18}\right)$
Berdasarkan tabel 1 dapat diketahui bahwa terdapat 6 karakter morfometri yang paling tinggi kontribusinya terhadap panjang total tubuh jantan. Karakter morfometri yang paling tinggi kontribusinya terhadap panjang total tubuh jantan yaitu panjang moncong hingga sebelum sirip dorsal pertama berkontribusi 97,3\%, panjang standard berkontribusi 98,3\%, panjang klasper berkontribusi 99,1\%, jarak antara sirip dorsal pertama dan kedua berkontribusi 99,3\%, panjang ekor berkontribusi 99,5\% serta panjang moncong hingga sebelum kepala berkontribusi 99,6\%.

Tabel 2 Karakter morfometri yang memberikan kontribusi terhadap panjang total pada Hiu Tupai (Chiloscyllium hasselti) Betina.

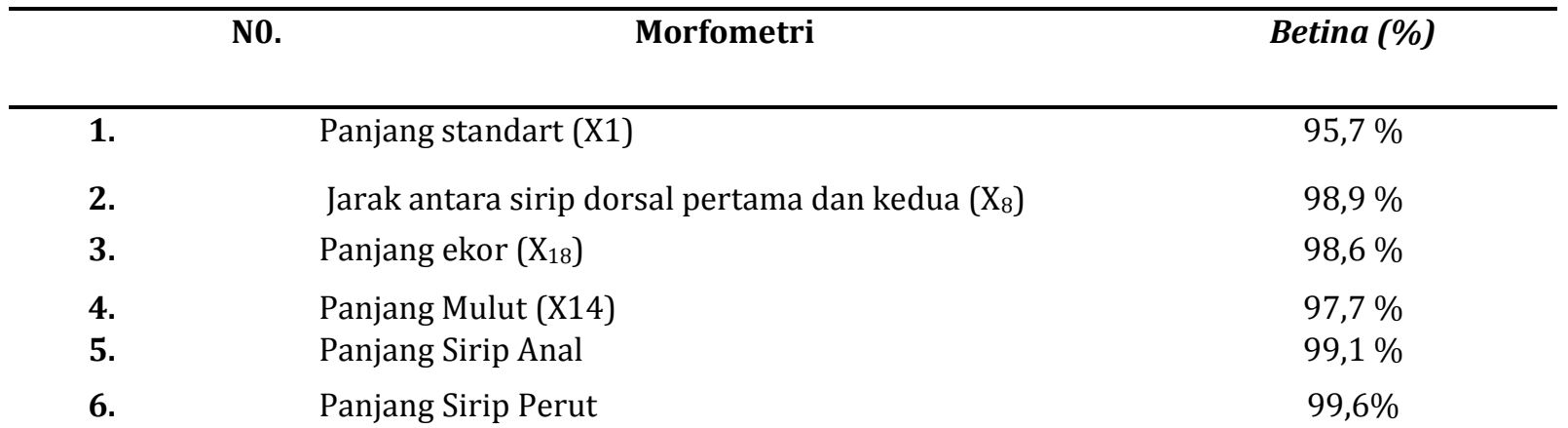

Berdasarkan Tabel 2 diatas diketahui karakter morfometri yang paling tinggi kontribusinya terhadap panjang total tubuh Hiu betina karakter tersebut adalah panjang standard berkontribusi 95,7 $\%$, panjang mulut berkontribusi $97,7 \%$, panjang ekor berkontribusi sebesar 98,6 \%, jarak antara sirip dorsal pertama dan kedua berkontribusi 98,9\%, panjang sirip anal berkontribusi 99,1 \% serta panjang sirip perut berkonribusi $99,6 \%$.

Tabel 3 Persamaan regresi berdasarkan kontribusi terhadap panjang total tubuh pada Hiu Tupai (Chiloscyllium hasselti) jantan dan betina

\begin{tabular}{ll}
\hline Hiu Tupai & Persamaan regresi \\
\hline Hiu Jantan & $Y=7,30+0,40 X_{2}+0,25 X_{1}+1,84 X_{20}+1,29 X_{8}+1,04 X_{18}+0,36 X_{5}$ \\
Hiu Betina & $Y=22,90+0,27 X_{1}+2,0 X_{14}+1,39 X_{18}+0,93 X_{8}-1,34 X_{19}+1,72 X_{11}$ \\
\hline
\end{tabular}


Perbedaan Morfometri Hiu Tupai (Chiloscyllium hasselti) Jantan dan Betina

Tabel 4 Perbedaan morfometri Hiu Tupai (Chiloscyllium hasselti) jantan dan betina

\begin{tabular}{|c|c|c|c|c|}
\hline \multirow[t]{2}{*}{ N0. } & \multirow[t]{2}{*}{ Morfometri } & \multicolumn{3}{|c|}{ Chiloscyllium hasselti } \\
\hline & & Jantan $(\mathrm{cm})$ & Betina $(\mathrm{cm})$ & $\mathrm{p}$ \\
\hline 1. & Panjang Total & $56,7 \pm 6,3^{a}$ & $60,5 \pm 6,3^{b}$ & 0.014 \\
\hline 2. & Panjang Standart & $45,7 \pm 5,1^{a}$ & $45,3 \pm 9,1^{a}$ & 0.771 \\
\hline 3. & $\begin{array}{l}\text { Panjang moncong hingga sebelum sirip } \\
\text { punggung pertama (PD1) }\end{array}$ & $25,2 \pm 2,8$ a & $26,6 \pm 5,6^{\mathrm{a}}$ & 0.131 \\
\hline 4. & $\begin{array}{l}\text { Panjang moncong hingga sebelum sirip } \\
\text { punggung kedua (PD2) }\end{array}$ & $36,6 \pm 2,6^{a}$ & $36,2 \pm 5,1^{\mathrm{a}}$ & 0.633 \\
\hline 5. & Panjang Kepala (HL) & $10,9 \pm 1,5^{a}$ & $9,3 \pm 3,1^{b}$ & 0.007 \\
\hline 6. & $\begin{array}{l}\text { Panjang moncong hingga celah insang } \\
\text { pertama (PGI) }\end{array}$ & $8,1 \pm 2,0$ a & $7,5 \pm 2,6$ a & 0.241 \\
\hline 7. & $\begin{array}{l}\text { Panjang moncong hingga sebelum spirakel } \\
\text { (PSP) }\end{array}$ & $5,1 \pm 0,6^{\text {a }}$ & $5,5 \pm 1,0^{b}$ & 0.017 \\
\hline 8. & $\begin{array}{l}\text { Panjang moncong hingga sebelum orbital } \\
\text { mata (POB) }\end{array}$ & $3,3 \pm 0,6^{\mathrm{a}}$ & $4,1 \pm 0,9^{b}$ & 0.000 \\
\hline 9. & $\begin{array}{l}\text { Jarak antara sirip punggung pertama dan } \\
\text { kedua(IDL) }\end{array}$ & $6,9 \pm 0,9 a$ & $7,2 \pm 1,8^{a}$ & 0.288 \\
\hline 10. & Jarak antara sirip dada dan sirip perut (PPS) & $8,6 \pm 0,8^{a}$ & $8,3 \pm 2,9^{a}$ & 0.661 \\
\hline 11. & $\begin{array}{l}\text { Panjang moncong hingga sebelum sirip perut } \\
\text { (PPL) }\end{array}$ & $22,8 \pm 1,9$ a & $24,2 \pm 3,1^{b}$ & 0.017 \\
\hline 12. & Panjang sirip perut(PSPE) & $5,3 \pm 0,7$ a & $5,6 \pm 0,9^{a}$ & 0.076 \\
\hline 13. & Jarak antara moncong dengan mulut(PP) & $2,3 \pm 0,4{ }^{a}$ & $2,7 \pm 0,4 b$ & 0.000 \\
\hline 14. & Lebar mulut (LM) & $4,4 \pm 0,3^{\mathrm{a}}$ & $3,8 \pm 0,7 \mathrm{~b}$ & 0.000 \\
\hline 15. & Panjang mulut (PM) & $1,9 \pm 0,8^{a}$ & $1,6 \pm 0,4^{b}$ & 0.032 \\
\hline 16. & Panjang sirip punggung pertama (DIA) & $6,8 \pm 1,3$ a & $6,3 \pm 1,1^{b}$ & 0.009 \\
\hline 17. & Panjang Sirip punggung kedua (D2A) & $5,7 \pm 0,7^{\mathrm{a}}$ & $5,8 \pm 0,7$ a & 0.145 \\
\hline 18. & Panjang sirip dada (PSDA) & $7,4 \pm 0,8^{a}$ & $8,0 \pm 0,8 b$ & 0.000 \\
\hline 19. & Panjang siripEkor(PE) & $7,2 \pm 1,4^{\mathrm{a}}$ & $9,1 \pm 1,8^{b}$ & 0.000 \\
\hline 20. & Panjang Sirip Anal(PSA) & $5,1 \pm 0,9^{a}$ & $5,7 \pm 1,2^{b}$ & 0.031 \\
\hline
\end{tabular}

Keterangan: Nilai rata-rata yang diikuti Superscript huruf yang sama dalam baris yang sama menunjukkan tidak ada perbedaan nyata berdasarkan uji t.

Berdasarkan data yang disajikan pada tabel diatas menjelaskan bahwa perbedaan Hiu Chiloscyllium hasselti hasil pengujian tersebut menunjukkan 12 karakter morfometri yang berbeda signifikan $(\mathrm{P}<0.05)$ dan 8 diantaranya tidak berbeda signifikan $(\mathrm{P}>0.05)$ terhadap 20 karakter yang diamati. Dari 12 karakter tersebut dapat menjadi acuan dalam identifikasi Hiu Chiloscyllium hasselti jantan dan betina. Karakter-karakter tersebut adalah panjang total, Panjang moncong hingga sebelum spirakel, panjang moncong hingga sebelum orbital mata,Panjang moncong hingga sebelum sirip perut, jarak antar moncong dengan mulut, panjang sirip dada, panjang sirip ekor, dan panjang sirip anal, 
panjang kepala, lebar mulut, panjang mulut, dan panjang sirip dorsal pertama.

\section{Pembahasan \\ Morfologi Hiu Tupai (Chiloscyllium hasselti) Jantan dan Betina}

Hasil pengamatan morfologi spesies Hiu Tupai (Chiloscyllium hasselti) yang ditemukansangat mirip dengan Chiloscyllium hasselti yang ditemukan oleh Ahmad dan Lim (2012) di Malaysia. Chiloscyllium hasselti memiliki ciri moncong pendek dan tumpul dengan sungut berdekatan dengan hidung, bagian permulaan sirip dorsal pertama bermula setengah setelah permulaan sirip pelvik. Jarak di antara kedua sirip dorsal pendek, permulaan sirip anal terletak setelah ujung sirip dorsal kedua yang tidak melekat pada badan.

Spesies Chiloscyllium hasselti memiliki sisi sirip dorsal bagian belakang yang berbentuk cembung, permulaan sirip pektoral terletak pada insang kedua atau ketiga, tidak ada pola warna pada dewasa sama halnya seperti yang ditemukan oleh (Ali et al., 2013).

Perbedaan morfologi HiuTupai Chiloscyllium hasselti jantan dan betina dapat dibedakan melalui organ reproduksi yang terdapat pada Hiu Tupai (Chiloscyllium hasselti) jantan dan betina. Hiu jantan memiliki klasper sedangkan pada Hiu betina memiliki kloaka. Semua ikan bertulang belakang menunjukkan perbedaan seksual jantan dan betina. Modifikasi sirip pelvik yang terdapat pada jantan. Modifikasi tersebut disebut klasper (Orlov and Cotton, 2011). Menurut Yano et al., (2005), klasper adalah alat kelamin jantan pada ikan bertulangrawan yang merupakan perpanjangan tulang bagian dalam dari sirip perut atau modifikasi sirip perut yang membentuk saluran sperma yang berfungsi menyalurkan sperma ke kloaka (organ reproduksi) betina atau organ kopulasi untuk memudahkan proses pembuahan secara internal.

Perbedaan morfologi Hiu Tupai Chiloscyllium hasselti jantan dan betina terdapat pada bentuk kepala. Bentuk sisi tepi kepala Hiu jantan tidak memiliki lekukan seperti pada kepala Hiu betina serta bentuk kepala Hiu betina yang lebih membulat dibandingkan jantan. Berdasarkan hasil penelitian Kajiura et al., (2005) perbedaan bentuk kepala antara jantan dan betina juga ditemukan pada ikan bertulang belakang (Chondrichthyes). Perbedaan spesies Hiu Sphyrina tiburojantan dan betina terdapat pada sisi depan bagian kepala. Hiu betina Sphyrina tiburo memiliki bentuk kepala yang lebih lebar dan membulat berbeda dengan jantan yang memiliki tonjolan disepanjang anterior kepala. Perbedaan pada bentuk kepala hiu terjadi karena faktor umur, habitat, dan genetiknya. Dharmadi dan Fahmi (2013) menambahkan pada habitatnya. Hiu hidup secara mengelompok hanya berdasarkan umur, ukuran, atu jenis kelamin yang sama. Hiu jantan hidup terpisah dari ikan betina sepanjang siklus hidupnya kecualipada saat musim kawin. Hal ini mengakibatkan perbedaan cara mendapatkan makanan dan adaptasi perilaku sosialnya yang berdampak pada pertumbuhan dan morfologi Hiu (Jacoby, 2011).

\section{Morfometri Hiu Tupai (Chiloscyllium hasselti) Jantan dan Betina}

Hasil penelitian menunjukkan bahwa Hiu Tupai (Chiloscyllium hasselti) jantan dan betina masing - masing memiliki 6 karakter yang berkontribusi terhadap panjang total tubuh. Karakter - karakter tersebut merupakan karakter yang memberikan sumbangsih terbesar terhadap panjang total tubuh dari 20 karakter morfometri yang diamati. Pada spesies Emipterus pusillus dan Emipterus spinax terdapat 6 karakter morfometri yang berkontribusi dari 27 karakter yang diteliti (Coelho and Erzini, 2008). Hasil penelitiann Rahayu, (2012) menyatakan bahwaterdapat 5 karakter yang berkontribusi pada $\mathrm{Hiu}$ betina Squalous megalops. Ke 6 karakter yang berkontribusi terhadap panjang total tubuh Hiu Tupai (Chiloscyllium hasselti) jantan dan betina tersebut dapat dijadikan rujukan sebagai penciri unuk mengidentifikasi Chiloscyllium hasselti jantan dan betina yang ditemukan dilapangan.

Pengaruh jenis kelamin terhadap morfometri terlihat pada hasil pengujian $u j i \mathrm{t}$ yang menunjukkan bahwa terdapat 12 karakter morfometri yang berbeda signifikan antara Hiu Tupai jantan dan betina terhadap 20 karakter yang diamati. Perbedaan karakter morfometri juga terdapat antara Hiu Scyliorhinus canicula jantan dan betina yang diteliti oleh Filiz and Taskavak (2006) yang memiliki 9 perbedan yang signifikan dari 28 karakter morfometri. Pada penelitian Martins et al., (2015) menyatakan bahwa terdapat 53 perbedaan karakter morfometri Carchanicus porosus jantan dan betina yang berbeda signifikan sedangkan Rhizoporionodon porosus jantan dan betina memiliki 54 perbedaan karakter morfometri yang berbeda signifikan dari 64 karakter morfometri yang diamati. Namun berbeda pada spesies Emipterus spinax dan Emipterus pusillushanya memiliki 1 perbedaan karakter morfometri antara jantan dan betina dari 27 karakter morfometri yang diamati (Coelho and Erzini, 2008). Dengan demikian semakin banyak 
pengamatan jumlah karakter yang diamati tidak menjamin karakter perbedaan jantan dan betina semakin banyak pula.

Panjang total tubuh Hiu Tupai (Chiloscyllium hasselti) jantan dan betina berbeda signifikan $(\mathrm{P}<0.05)$. Panjang total tubuh Hiu Tupai betina lebih besar dibandingkan dengan panjang total Hiu Tupai jantan. Hal ini disebabkan karena hiu betina lebih membutuhkan energi yang lebih besar untuk proses reproduksi dan menjaga anaknya. Panjang total tubuh Hiu betina lebih besar daripada hiu jantan kecuali untuk famili scyliorhinidae (cat shark) (Compagno et al., 2001). Hal tersebut dibuktikan dalam penelitian Filitz and Taskavak (2006) yang mengamati perbedaan panjang total tubuh hiu Scyliorhinus canicula famili scyliorhinidae (cat shark) Hiu jantan lebih besar dibanding dengan Hiu betina. Spesies Holoharaelulurus regani termasuk famili scyliorhinidae memiliki panjang total tubuh jantan lebih besar dibanding dengan panjang total tubuh Hiu betina (Rhichardson et al., 2000). Panjang total tubuh Hiu betina Rhizoporionodon lalandi famili carchahinidae lebih besar dibanding Hiu jantan (Lessa et al., 2009).

Panjang moncong hingga sebelum spirakel, panjang moncong hingga sebelum orbital mata dan panjang moncong hingga sebelum sirip perut pada Hiu Tupai (Chiloscyllium hasselti) jantan dan betina berbeda signifikan $(\mathrm{P}<0.05)$. Hiu betina memiliki panjang moncong hingga sebelum spirakel, panjang moncong hingga sebelum orbital mata dan panjang moncong hingga sebelum sirip perut lebih panjang dibanding dengan Hiu jantan. Filitz and Taskavak (2006), menemukan perbedaan yang signifikan antara Hiu Scyliorhinus canicula jantan dan betina pada panjang moncong hingga sebelum spirakel $(\mathrm{P}$ $<0.05$ ). Namun hal yang berbeda pada hasil penelitian Coelho and Erzini, (2008) Emipterus pusillus jantan dan betinanya tidak memiliki perbedaan yang signifikan pada panjang moncong hingga sebelum orbital.

Jarak moncong dengan mulut pada Hiu Tupai (Chiloscyllium hasselti) jantan dan betina berbeda signifikan $(P<0.05)$. Hiu Tupai betina memiliki jarak moncong dengan mulut yang lebih panjang dibanding dengan Hiu jantan. Erdogan et al., (2004) menemukan perbedaan jarak moncong dengan mulut (peroral) yang signifikan antara Hiu Scyliorhinus canicula jantan dan betina. Jarak moncong dengan mulut Hiu jantan Scyliorhinus canicula lebih pendek dibandingkan betina.

Lebar mulut, panjang mulut, dan panjang sirip dorsal pertama Hiu Tupai (Chiloscyllium hasselti) jantan dan betina berbeda signifikan $(\mathrm{P}<0.05)$. Hiu jantan memiliki lebar mulut yang lebih lebar dan panjang mulut serta panjang sirip dorsal pertama yang lebih panjang dibandingkan dengan hiu betina. Perbedaan tersebut terdapat juga pada spesies Scyliorhinus canicula yang memiliki lebar mulut yang lebih lebar dan panjang mulut yang lebih panjang dibanding dengan Hiu betinanya (Filitz and Taskavak, 2006). Perbedaan panjang mulut dan lebar yang signifikan juga dijelaskan pada penelitian Martins et al., (2015) Hiu Carchanicus porosus jantan memliki panjang mulut yang lebih panjang dibanding betinanya sedangkan Rhizoporinodon porosus jantan memiliki lebar mulut yang lebih lebar dibanding Hiu betinanya. Panjang mulut dan lebar mulut Hiu jantan lebih lebar dibanding Hiu betina disebabkan karena perbedaan cara mendapatkan makanan pada habitatnya dan perilaku reproduksi (Filitz and Taskavak, 2006).

Panjang sirip dada, panjang sirip anal serta panjang ekor Hiu tupai (Chiloscyllium hasselti) jantan dan betina berbeda signifikan $(\mathrm{P}<0.05)$. Hiu betina memiliki panjang sirip dada, panjang sirip anal serta panjang ekor yang lebih panjang dibanding dengan Hiu jantan. Adanya perbedaan karakter morfometri dan morfologi menunjukkan bahwa Hiu mampu dibedakan atas jantan dan betinanya. Variasi morfometri suatu populasi pada kondisi geografi yang berbeda dapat disebabkan oleh perbedaan struktur genetik dan kondisi lingkungan (Tzeng et al., 2000).

\section{Kesimpulan}

Berdasarkan hasil penelitian yang dilakukan diperoleh kesimpulan sebagai berikut:

1. Terdapat perbedaan morfologi Hiu Tupai (Chiloscyllium hasselti) jantan dan betina terlihat pada bentuk kepala dan organ reproduksi. Bentuk sisi tepi kepala Hiu jantan tidak memiliki lekukan seperti pada kepala Hiu betina serta bentuk kepala Hiu betina yang lebih membulat dibandingkan jantan. Hiu jantan memiliki klasper sedangkan pada hiu betinanya tidak memiliki klasper.

2. Terdapat perbedaan secara morfometri Hiu Tupai (Chiloscyllium hasselti) jantan dan betina memiliki 12 karakter perbedaan.

3. Karakter morfometri yang paling tinggi kontribusinya terhadap panjang total tubuh Hiu Tupai (Chiloscyllium hasselti) jantan yaitu panjang sebelum sirip dorsal pertama berkontribusi 97,3\%, panjang standard berkontribusi 98,3\%, panjang klasper berkontribusi $99,1 \%$, jarak antara sirip dorsal 
pertama dan kedua berkontribusi 99,3\%, dan panjang ekor berkontribusi $99,5 \%$ dan panjang sebelum kepala berkontribusi 99,6\%. Sedangkan pada Hiu betina karakter morfometri yang paling berkontribusi yaitu panjang standard berkontribusi 95,7 \%, panjang mulut berkontribusi 97,7 \%, panjang ekor berkontribusi sebesar 98,6 \%, jarak antara sirip dorsal pertama dan kedua berkontribusi 98,9\%, panjang sirip anal berkontribusi 99,1 \% serta panjang sirip perut berkonribusi 99,6\%.

\section{Saran}

Perlu dilakukan penelitian selanjutnya tentang proporsi berat dan pengukuran lebar kepala terhadap panjang total tubuh antara Hiu Tupai (Chiloscyllium hasselti) jantan dan betina.

\section{Daftar Pustaka}

Ahmad, A., dan Lim A.P.K., (2012), Field Guide $\quad$ to Shark of Southeast Asian Region, Perpustakaan Negara Malaysia, Malaysia.

Ali, A., Lim, A.P.K., Fahmi and Dharmadi, (2013) Field Guide to Look-alike Sharks and Rays, SEAFDEC, Malaysia

Bangun,V.O, (2014), Efektivitas Cites (Convention On International Trade in Endangered Species of Wild Fauna And Flora) dalam Mengatur Perdagangan Hiu di Kawasan Coral Triangel (Implementasi di Indonesia), Journal FISIP, 1 : 4-9

Camhi, M, S. Fowler, J.A. Musick, A. Brautigam dan S. Fordham, (1998), Sharks and Their Relatives, Ecology and Conservation, Occasional Paper of IUCN Species Survival Commision No. 20 IUCN, Cambridge.

Chen, W.K., P.C. Chen, K.M. Liu, S.B. Wang, (2007), Age and Growth Estimates of the Whitespotted Bamboo Shark, Chiloscyllium plagiosum, in the Northern Waters of Taiwan, Zoological Studies 46 : 92-102.

Coelho, R., and Erzini, K., (2008), Identification of Deep Water Latern Sharks (Chondrichthyes: Etmopteridae) Using Morphometric Data and Multivariate Analysis, Journal Marine Biology Association of The United Kingdom, 88 : 199204.

Compagno, L.J.V, (2001), Shark of The World; An Annotated Illustrated Catalogue of The Shark Species Know to Date, FAO Rom, 2 : 1-3.

Dharmadi dan Fahmi, (2013), Tinjauan Status Perikanan Hiu dan Upaya Konservasinya di Indonesia. Edisi Pertama, Direktorat
Konservasi Kawasan dan Jenis Ikan, Direktorat Jenderal Kelautan, Pesisir dan Pulau-Pulau Kecil, Kementrian Kelautan Dan Perikanan, Jakarta.

Erdogan, Z.A., Koc, H.T, Cakir, D.T, Nerlovic, V., dan Dulcic, J., (2004), Sexual Dimorphism in the Smallspotted Catshark, Scyliorhinus canicula (Linnaeus, 1758) from Endremit Bay (Turkey), Series Historia Naturalis, 14 : 165169.

Faizah, R dan Umi, C, (2015), Struktur ukuran dan nisbah kelamin ikan Cucut Kejen (Carcharhinus falciformis) Di Perairan Selatan Nusa Tenggara Barat, Simposium Hiu dan Pari Indonesia, 1 43-48.

Filiz H, and Taşkavak E, (2006), Sexual Dimorphism in the Head, Mouth, and Body Morphology of the Smallspotted Catshark, Scyliorhinus canicula (Linnaeus, 1758) (Chondrichthyes: Scyliorhinidae) from Turkey, Acta Adriatica 47 : 37-47.

Idris, H.B., M.A. Ambak, I. Abdullah, (2012), Sex Determination in Oxyeleotris marmorata (Bleeker, 1852) Based on Morphometric Features, Journal Advances in Natural and Applied Sciences, 6 : 763-771.

Irschick, J.D., dan Hammerschlag, N, (2014), Morphological Scaling of Body form in Four Shark Species Differing in Ecology and Life History, Biological Journal of the Linnean Society, 1-10.

IUCN, (2016), http// iucnredlist.org/ 10.20305 / IUCN.UK.2009-2RLTS (2 Maret 2016).

Jacoby, D. M.P, Croft, D.P and Sims , D. W, (2011), Social behaviour in sharks and rays: analysis, patterns and implications for conservation, Fish and Fisheries, 1-19

Kajiura, S.M., Tyminski, J.P., Forni, J.B, Summers, P.A., (2005), The Sexually Dimorphism Cephalofoil of Bonnethead Sharks, Sphyrna tiburo, Biological Bulletin, 209 : 1-5.

Lessa, R., Santana, F.M., Almeida, Z., (2009), Age and Growth of The Brazillian Sharpnose Shark, Rhizoporionodon lalandii and Caribean Sharpnose Shark, $R$ Porosus (Elasmobranchii, Carcharhinidae) on the northen coast of Brazil (Maranhao), Pan American Journal of Aquatic Sciences, 4 : 532-534.

Martins, B.A.P., Filho, S.E., Feitosa, L.M., Silva, N.L.P., Almeida, S.Z., dan Nunes, S.J.L., (2015), Sexual Dimorphism of Shark from the Amazonian Equatorial Coast, Journal Universitas Scientiarum, 20 : 297-304. 
Orlov, A.M dan Cotton, C.F, (2011), Sexually Dimorphic Characters in Five North Atlantic Deepwater Skates (Chondrichthyes: Rajiformes), Journal of Marine Biology, 1 (1): 1-18.

Piorski, N.M., and Nunes (2001), Dimorphism Sexual and Alomatrica Urotrygon microphthalmum Deslman, 1941 (Elasmobranchii: Urolophidae), Buletim laboratoy hidrobiology, 13:67-81.

Rahayu, P, dan Sudibyo, M, (2016), Kajian Morfologi, Morfometri, dan Status Konservasi Hiu yang Ditemukan Di Sumatera Bagian Utara, Jurnal Biosains, 2 : 1-7.

Richardson, A.J., Maharaj, G., Compagno, L.J.V., Leslie, R.W., Ebert, D.A., dan Gibson, M.J., (2000), Abdundance, Distribution, Morphometrics, Reproduction and Diet of the Izat Catshark, Journal of Fish Biology, 56: 552-576.

Tzeng, TD., Chiu., Yeh, S-Y, (2000), Morphometric Variation in Red-spot prawn (Metapenaeopsis barbata) in Different Geographic Waters, Journal Fisheries Research 53 : 211-217

White, W.T, P. R. Last, J. D. Stevens, G. K. Yearsley, Fahmi, Dharmadi, (2006), Economically Important Shark and Rays Indonesia ( Hiu dan Pari yang bernilai Ekonomi penting Indonesia), Australian Centre for International Agricultural Research, Australia.

WWF, (2015), Panduan Penanganan Hiu sebagai Tangkapan Sampingan (Bycatch), WWF, Indonesia

Yano, K., A. Ali, A. C. Gambang, I. A. Hamid, S. A. Razak, A. Zainal, (2005). Sharks and rays of Malaysia and Brunei Darussalam. Marine Fishery Research Development and Management Departem ent Southeast Asian Fisher ies Development Center. Terengganu, Malaysia. 